\title{
O Sagrado e as mulheres quilombolas: experiência religiosa das rezadeiras da comunidade do Baixão - BA
}

\author{
Washington SANTOS NASCIMENTO (iD \\ Universidade do Estado do Rio de Janeiro | Rio de Janeiro, RJ, Brasil \\ washingtonprof@gmail.com \\ VIVIAN INGRIDY CARVALHO LIMA \\ Universidade Estadual do Sudoeste da Bahia | Vitória da Conquista, BA, Brasil \\ vivianpsicoufba@gmail.com
}

DOI 10.11606/issn.2316-9133.v30i1pe172066

resumo $\mathrm{O}$ artigo pretende compreender a experiência religiosa de mulheres rezadeiras da Comunidade Quilombola do Baixão, localizada na região Sudoeste da Bahia. A pesquisa realizada durante o período de outubro de 2016 a março de 2018, que utilizou como metodologia de trabalho a História Oral, permitiu compreender como a experiência religiosa de duas rezadeiras da comunidade, que tem seus saberes baseados no catolicismo e na ancestralidade de matriz africana, se engendra num sistema complexo mágico-religioso que regula o cotidiano do quilombo. As rezadeiras e os seus altares tornaram-se o centro da nossa análise porque contam muito da história dessas mulheres e da comunidade. Os altares são considerados espaços sacralizados e socialmente identificados, imbuídos de um significado memorialístico, sobrenatural e, ao mesmo tempo, são referências para o entendimento, ao menos em parte, do que se constituem essas mulheres, dentre outros atributos e papéis sociais, como negras, lideranças religiosas e moradoras de comunidade rural.

palavras-chave Experiência religiosa. Gênero. Ancestralidade

\footnotetext{
The sacred and the quilombola women: the religious experiences of rexadeiras in the community of Baixão, Bahia, Brazil

abstract The article intends to understand the religious experience of rezadeiras, worshipers women, from Baixão, a Quilombola Community located in Southwestern Bahia, in Brazil. The data collection was from October 2016 to March 2018 and used methods based on the Oral History methodology. From this approach, the researchers attempt to understand how
} 
the religious experience of two religious women in the community is engendered in a complex magical-religious system that regulates the daily life of the quilombo. In addition, the knowledge of these subjects is based on Catholicism and ancestry of African matrix. The rezadeiras and their altars became the center of the analysis since they stand for the story of these women and the community. The altars are considered sacred and socially identified spaces, imbued with a memorialistic, supernatural meaning. At the same time, even partially, the alts refer to what these women are and their social constituencies as black women, religious leaders, and rural community residents.

keywords Religious experience. Gender. Ancestry.

\section{El sagrado y las mujeres quilombolas: las experiencias religiosas de las rezadeiras en la comunidad del Baixão, Bahia, Brasil}

resumen El artículo busca comprender la experiencia religiosa de las rezadeiras (mujeres oradoras) en la Comunidad quilombola del Baixão, ubicada en la región suroeste de Bahía. La investigación fue realizada entre octubre de 2016 y marzo de 2018, y fue basada en los métodos de la Historia Ora. De ahí fue posible comprender cómo se configuró la experiencia religiosa de dos rezadeiras de la comunidad. El conocimiento que estas señoras producen se basa en el catolicismo y en la ascendencia africana, haciendo parte de en un complejo sistema mágicoreligioso que regula la vida cotidiana del quilombo. Las rezadeiras y sus altares se convirtieron en el centro del análisis porque cuentan mucho sobre la historia de estas mujeres y la comunidad. Los altares son considerados espacios sagrados y socialmente identificados, imbuidos de un significado memorialista, sobrenatural y, al mismo tiempo, son referentes para la comprensión, al menos en parte, de lo que son estas mujeres, entre otros atributos y roles sociales, como negros, líderes religiosos y residentes de comunidades rurales.

palabras clave Experiencia. Género. Ancestralidad.

\section{Introdução}

Dona Bezinha é uma das rezadeiras mais antigas do Baixão, comunidade quilombola localizada a $13 \mathrm{~km}$ da cidade baiana de Vitória da Conquista, sudoeste da Bahia. A formação da comunidade se deu a partir do entrelaçamento entre indígenas e descendentes de africanos, há aproximadamente 150 anos. Conforme a oralidade dos moradores mais velhos, os primeiros moradores daquele território surgiram a partir da união entre as famílias Machado, de Deus (os Malaquias) e de Jesus, além de um morador "chegante" na comunidade que era indígena. A comunidade quilombola do Baixão retrata a base ancestral e a diversidade religiosa do sudoeste baiano: de São Jorge a Janaína, “aquela que tem rabo", “os guias bons e sujos”, crenças que são a porta de entrada para entender também aspectos ligados às práticas de cura e ao universo míticoreligioso que são construídos e perpetuados naquele espaço social. Dessa maneira, a partir da 
concepção de Clifford Geertz (1989), Mircea Eliade (1972; 1992) e Claude Lévi-Strauss (2008), este estudo pauta-se na análise da experiência religiosa de duas rezadeiras da comunidade, bem como problematizar sobre o status de sacralidade que adquirem nas práticas religiosas, especialmente nos altares, e estão ligados diretamente ao processo de significação da experiência humana, sobretudo à ancestralidade de matriz africana. A ancestralidade, proposta epistemológica para o entendimento sobre o entrelaçamento entre gênero e experiência religiosa na comunidade do Baixão, tem como horizonte o debate feito por Goldman (2012), Oliveira (2012; 2018), Póvoas (2011), Prandi (2000; 2010) e Sansi (2009).

A discussão sobre gênero por sua vez, propõe evidenciar o protagonismo de duas rezadeiras do Baixão, discutindo como a experiência religiosa, isto é, os saberes e fazeres do universo mágico-religioso se engendram em outras redes de saberes ancestrais que regulam o cotidiano da comunidade, desestabilizando as noções tradicionais dos papéis sociais que têm em suas raízes o patriarcado das famílias dos Machado e dos Malaquias. As mulheres da comunidade se destacam por desenvolver diferentes atividades e estarem em diferentes espaços sociais, ora sendo rezadeiras, feirantes, comerciantes, líderes comunitárias, lavradoras, líderes espirituais, além de serem as principais referências de ancestralidade negra entre seus moradores.

Como categoria analítica, gênero pode ser entendido como uma "identidade subjetiva" e está atrelada a outras categorias como raça, etnicidade e classe, tal como "uma linguagem conceitual que estabeleça fronteiras e contenha, ao mesmo tempo, a possibilidade da negação, da resistência, da reinterpretação e permita o jogo da invenção metafórica e da imaginação" (Scott 1995: 86).

Ampliando o arcabouço teórico dessa discussão, gênero é visto aqui a partir de uma análise decolonial, uma vez que por se tratar de um estudo voltado para a realidade latinoamericana, tal análise nos possibilita lançar rupturas de uma episteme colonial, baseada num feminismo eurocêntrico e antropocentrado que produz relações hierarquizantes e de opressão (Bernardino-Costa; Grosfoguel 2016; McClintock 2010; Segato 2012; Carneiro 2011). Trata-se de analisar como as categorias - interseccionalidade, raça, religião, classe, etnia e gênero, "trabalhando em redes, são ao mesmo tempo causa e efeito $\mathrm{d}(\mathrm{n})$ a criação dos conceitos umas das outras" (McClintock 2010 apud Gomes, 2018: 71).

Desse modo, discutir neste texto a categoria gênero propõe o rompimento de generalizações. Ser mulher no Baixão não se desvincula de ser negra, moradora de comunidade rural e inserida em redes de saberes (feiras, futebol feminino, lideranças comunitárias, dentre outras) fundamentais para manutenção da oralidade e da perpetuação do conhecimento ancestral.

Pensar no protagonismo dessas rezadeiras, é evidenciar uma relativa igualdade ou transitoriedade dos papéis sociais no que se refere a experiência religiosa, já que a construção binária moderna, não responde, ao menos parcialmente, como as interações entre sagrado e 
profano são construídas ao longo do tempo e operam na produção do conhecimento cotidiano na comunidade.

Outra categoria que sustenta o campo de investigação na comunidade quilombola é a etnicidade, que é tecida nas interações sociais e compartilhada pelas redes de saberes ancestrais do grupo e no grupo, onde eles se auto identificam e são identificados por outros enquanto quilombolas e, em particular, pertencente a uma determinada parentela "a partir de determinados traços culturais, psicológicos ou físicos, ou uma combinação deles, que são erigidos em marcadores simbólicos do grupo, sinais publicamente reconhecidos que fundamentam uma relação contrastante entre os grupos étnicos" (Poutignat; Streiff-Fernat 1998: 152). Dito de outro modo, etnicidade é o esteio que permite a perpetuação e ressignificação desses saberes que transitam em diferentes gerações. Nesse sentido, chamamos de rede de saberes o entrelaçamento de todo esse conhecimento que tem como pilar a transmissão oral pelos mais velhos aos mais jovens. Esse termo, rede de saberes, melhor caracteriza a etnicidade imbrincada no processo de significação e ressignificação dessas práticas. $\mathrm{O}$ que nos faz pensar que a etnicidade e ancestralidade podem ser consideradas aqui como categorias análogas e ou que se amalgamam.

Para investigar o contexto sócio-histórico da experiência religiosa das rezadeiras da comunidade, a pesquisa contou com a metodologia de trabalho a História Oral (Silveira 2007; Portelli 2000; Meihy 2000; 2005), por ser uma alternativa na busca por igualdade e pelo diálogo, do ponto de vista político, dá voz às memórias de pessoas colocadas no anonimato. É válido salientar que há diferentes versões sobre a história da comunidade do Baixão e que há diferentes construções sobre um mesmo fenômeno, sendo que esta metodologia nos ajuda a pensar sobre a trajetória dessas mulheres para além de uma verdade absoluta e de uma memória oficial.

Paralela às discussões sobre História Oral, Pollack (1989; 1992) contrapõe o campo de pesquisa que privilegia uma "memória oficial" e homogeneizadora, defendendo o deslocamento de investigação para uma "memória subterrânea", como um "elemento constituinte do sentimento de identidade, tanto individual quanto coletiva, na medida em que ela é também um fator extremamente importante para o sentimento de continuidade e de coerência de uma pessoa ou de um grupo em sua reconstrução de si” (Pollack 1992: 204).

Assim, a memória dos moradores mais velhos sobre o passado histórico da comunidade é marcada por trajetórias de resistência, em que os relatos de castigos e práticas análogas ao período da escravidão mantêm vivo o elo entre os atuais moradores e seus ancestrais. A memória é considerada neste estudo como mediadora entre as categorias: religião, gênero, etnicidade e ancestralidade. ${ }^{1}$

\footnotetext{
${ }^{1}$ Para saber mais sobre os trânsitos, pertencimentos e a construção da identidade quilombola na comunidade quilombola do Baixão, consultar: Lima; Nascimento (2018).
} 
Ser quilombola na comunidade perpassa por uma construção recente e implica dois processos de interação social: o primeiro é político, que consiste no reconhecimento de sua própria história e no engajamento nas lutas diárias do quilombo, a exemplo a Associação Comunitária que em sua maioria é composta por mulheres; o segundo, que é o cerne da discussão proposta aqui, refere-se ao protagonismo de duas rezadeiras que perpetuam os saberes ancestrais através da religiosidade, das tradições, da memória, da oralidade e que ressignificam essas práticas que no passado era privilegiada apenas para os homens da comunidade.

Com efeito, este artigo inicia com uma discussão sobre a experiência religiosa na comunidade quilombola do Baixão, que se desmembra em dois eixos centrais: o primeiro é a análise mais detalhada sobre a religiosidade de duas mulheres rezadeiras, consideradas as guardiãs desse e de outros saberes, e o segundo eixo, parte da análise de seus altares e a importância desses símbolos para a constituição dessas rezadeiras enquanto mulheres negras, líderes religiosas e moradoras de comunidade rural que têm as suas referências na ancestralidade e na transmissão oral do conhecimento.

\section{Ancestralidade e experiência religiosa na comunidade}

Estar em comunidade faz parte das raízes do Baixão. Tudo é motivo para estar em comunhão, que tem como base os princípios de solidariedade e de parentesco. Em seus rituais religiosos, a figura das mulheres mais velhas, conhecidas como rezadeiras, tem um significado importante para a manutenção e perpetuação desses saberes e fazeres. Neste processo memorialístico da ancestralidade, as rezadeiras têm a função de perpetuar esse saber escutado e guardado por meio de conversas e símbolos como uma "memória tomada de empréstimo" num contínuo de ressignificações em que as tornam, as "guardiãs da memória" (Halbwachs 2006), "tradicionalistas” (Bâ 1982).

No Baixão a experiência religiosa está ancorada na relação que os moradores têm com seus ancestrais, que estão vivos na memória coletiva e são representados em diferentes saberes, práticas e símbolos, a exemplo, do oratório e dos instrumentos do Terno de Reis São João da Paz que há quatro décadas acompanham o Mestre e seus foliões. A experiência religiosa está vinculada a um dom herdado dos antepassados. Por outro lado, à concepção de ancestralidade, destacamos a defendida por Oliveira (2012), que reivindica uma episteme baseada na Filosofia da Ancestralidade, isto é, na tradição dinâmica dos povos africanos. A Filosofia da Ancestralidade faz uma crítica à filosofia dogmática e universalizante e desenvolve o conceito de ancestralidade para muito além de relações consanguíneas ou de parentesco simbólico.

Retomando para as mulheres rezadeiras do Baixão, podemos pensar como a experiência religiosa está para além de ensinamentos perpetuados de geração em geração. A ancestralidade é uma categoria que nos ajuda a pensar como estas mulheres constroem formas singulares de se relacionar com o mundo, quer seja o espiritual, o profano, o intrapessoal e o coletivo. Dessa 
maneira, na comunidade a experiência religiosa se manifesta nas relações sincréticas de mistura e mestiçagens presentes nos saberes e rituais religiosos que compõem a Romaria a Bom Jesus da Lapa, as Ladainhas, as procissões em homenagem a santos, os Carurus, dentre outras práticas que direta ou indiretamente tem relação com o sagrado e permeiam o cotidiano da comunidade.

\section{As Ladainhas}

De um modo especial, as Ladainhas são uma espécie de culto aos ancestrais e as entidades e santos do Candomblé, Umbanda e do catolicismo e representam o patrimônio memorialístico ressignificado e repassado de geração a geração.

Como práticas itinerantes realizadas por grupos de rezadeiras, as Ladainhas, em homenagem a santos do catolicismo e entidades de matriz africana, acontecem simultaneamente nas residências dos moradores, geralmente às 8 horas da manhã e se encerram às 23 horas, isso para os Santos de maior popularidade e devoção entre os moradores, como é o caso de Nossa Senhora Aparecida, Santa Luzia e São Sebastião.
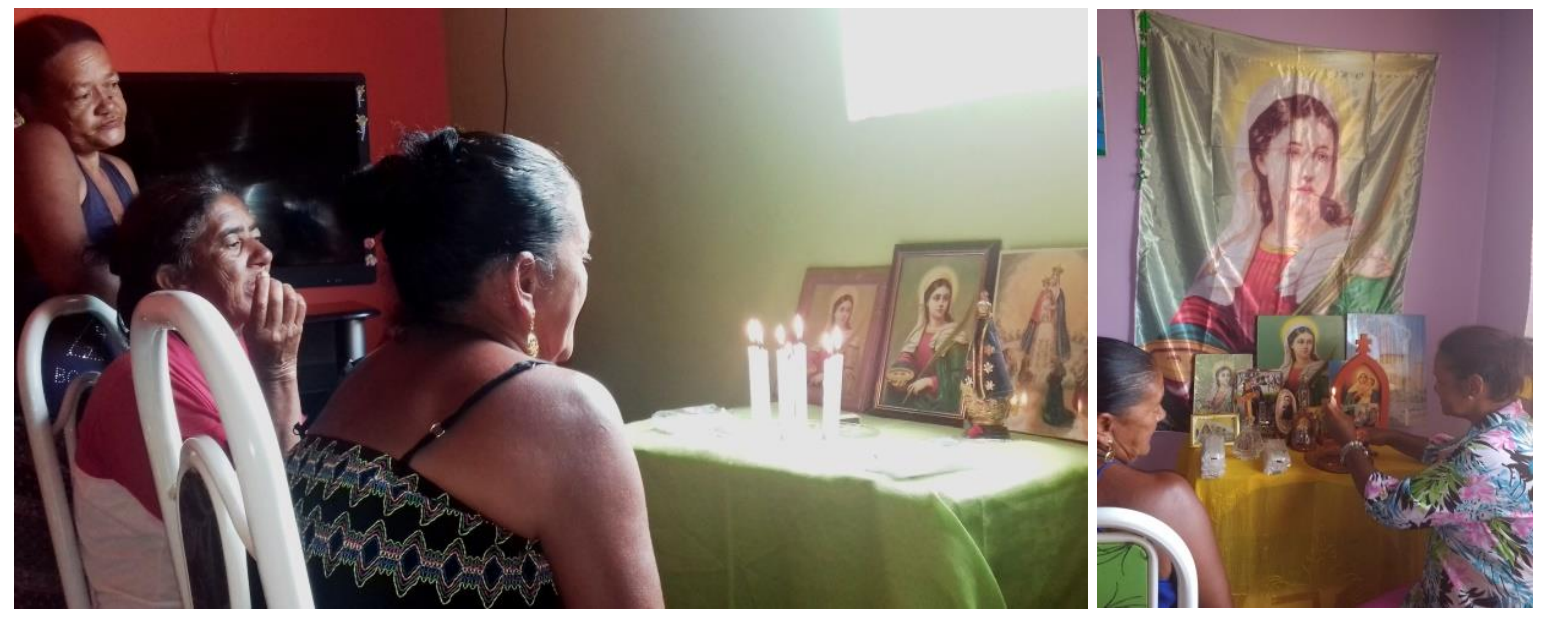

Figura 1. Rezadeiras de Ladainha em homenagem a Santa Luzia. Fonte: Acervo da pesquisa, outubro de. 2017

É comum as rezadeiras ficarem em frente ao altar, enquanto outras mulheres ficam acompanhando o ritual posicionadas atrás das rezadeiras. O ritual é caracterizado por etapas que se iniciam com rezas e ladainhas específicas que demarcam o início, meio e fim. A primeira parte, as orações começam com Deus vos salve, o Pai Nosso e o Terço. A Ladainha, que é considerada a parte do meio, é seguida da oração de Salve Rainha e os cânticos benditos ao santo ou santa homenageada. Nesta parte do rito a Ladainha também é cantada em Latim.

É válido destacar que ainda que as rezadeiras sejam mulheres não alfabetizadas ou com baixa escolaridade, ao longo do tempo aprenderam com seus antepassados a oração em Latim, ressignificando-a, a exemplo Mater, que segundo as rezadeiras se refere à Santa Marta. Quando 
foi pedido para Dona Bezinha dar uma demonstração da Ladainha cantada para a Santa, ela faz a seguinte ponderação:

Ah... pra cantar é muito grande. Só Marta é sete palavras de Marta. Regina é sete [...] A Marta é Nossa Senhora mesmo. E Regina, também é a mesma coisa. Então elas é coligada, elas tudo em Latim, hora que começa a Ladainha, Nossa Senhora joelha, agora ela faz o chama e as outras tudo encosta. Agora quando oferece, oferece pra elas tudo. (Entrevista Dona Bezinha, setembro/2017 - Grifos nossos).

A parte final, chamada de viva pelas rezadeiras, é o momento em que elas acenam em agradecimento para as divindades que foram aclamadas. Abaixo segue um trecho de uma Ladainha cantada pelas rezadeiras em homenagem a Santa Luzia:

Lá no céu ela foi a Senhora Santa Luzia

Quando Ela perdeu as vista e que perdeu a luz do dia

Que o pranto que aparava, lábios de Santa Luzia

Quando retornou as vistas que enxergou a luz do dia

Lá no céu ela foi a Senhora Santa Luzia

Minha virgem Santa Luzia

Minha virgem das vistas acode com seus milagres

Ôh Senhora Santa Luzia

Minha virgem Santa Luzia, minha virgem das vistas

Apegai com Bom Jesus que eu te darei as vistas

Ôh virgem bendita orai senhor que está na cruz [...].

Finalizado os ritos da ladainha, geralmente é servido algum alimento para as rezadeiras e aos visitantes, isso depende das condições financeiras de cada morador, mas independente do que é servido, é recebido com muita satisfação entre as religiosas. $O$ ato de compartilhar o alimento está associado aos rituais de diferentes religiões. No catolicismo, por exemplo: ceia natalina, domingo de Páscoa, Hóstia, entre outras. No candomblé é uma ligação entre as entidades e os humanos.

Em algumas casas, o clima de festividade culmina na distribuição de bebidas alcoólicas para todos que estão ali para acompanhar a Ladainha. No entanto, o consumo de bebidas só é permitido na parte externa da casa, pois na parte interna há os altares com os símbolos e imagens de santos de devoção da família. Estes aspectos que refletem a fronteira e a intersecção entre o sagrado e o profano da experiência religiosa no Baixão, especificamente nos rituais da Ladainha. 
Diferentemente do passado, a presença de homens neste ritual se dá de forma discreta e em sua maioria não se torna relevante. Para eles são encarregados apenas à queima de fogos, caso seja solicitado pela família. Eles devem acompanhar as Ladainhas do lado de fora das casas. Concluído todos os rituais sagrados e profanos da Ladainha, as rezadeiras seguem em procissão para outras residências, dando continuidade a peregrinação.

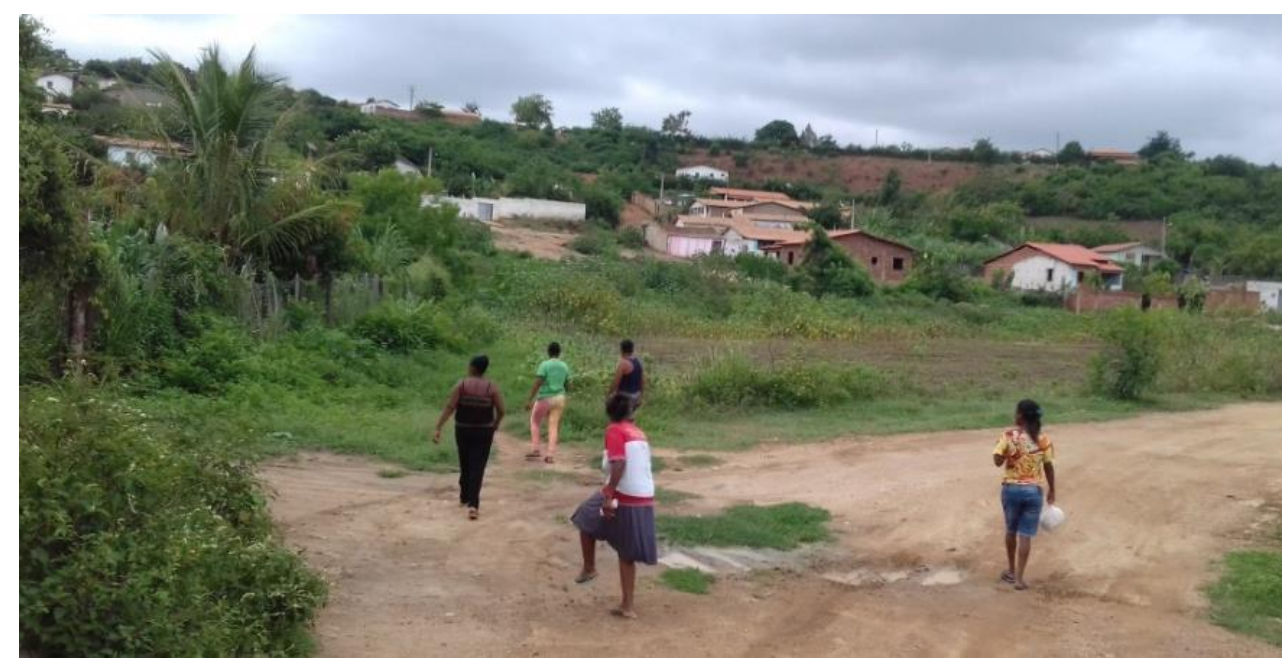

Figura 2. Rezadeiras em itinerâncias pela comunidade. Fonte: Acervo da pesquisa, outubro de 2017

$\mathrm{Na}$ análise sobre a experiência religiosa no Baixão, não cabe a nós, meros pesquisadores, validar ou separar o que é de influência europeia, indígena ou afro-brasileira, uma vez que para formar esse sistema de crenças mágico-religiosas, a comunidade criou ao longo do tempo estratégias para preservação ou extinção deste ou daquele mito, rito ou magia. Ao passo que também é difícil estabelecer uma temporalidade sobre a mudança dos papéis sociais na comunidade e a incorporação e assimilação de novos elementos, sendo que no passado, estas práticas religiosas eram fortemente marcadas pela presença masculina. ${ }^{2}$

\section{As rezadeiras e seus altares}

Atualmente a experiência religiosa no Baixão tem como referência os ensinamentos de duas rezadeiras mais antigas da comunidade, Izabel Tereza de Jesus (Bezinha) e Jesuína Teresa de Jesus (Tuga), onde em suas casas os altares tornam-se espaços imbuídos de um significado

\footnotetext{
${ }^{2}$ Outro exemplo sobre a incorporação de novos elementos no conjunto de crenças e rituais ocorre no Reisado. Durante a Folia do Ternos de Reis, os moradores da casa que recebem os foliões jogam dinheiro no chão e os participantes do Terno devem pegar com a boca o donativo sem interromper a cadência musical dos instrumentos. Este momento é considerado o ápice da experiência individual e coletiva e ocorre como uma espécie de transe ao que é chamado por eles como a Chula.
} 
memorialístico, histórico, social, místico e sobrenatural. ${ }^{3}$ Elas são primas de primeiro grau, além de terem trajetórias de vida parecidas: a relação com a terra e a natureza, não alfabetizadas, cultivam práticas de plantio e criação de animais, foram feirantes, utilizaram diferentes estratégias de sobrevivência, tornando-as as principais mantenedoras da renda familiar.

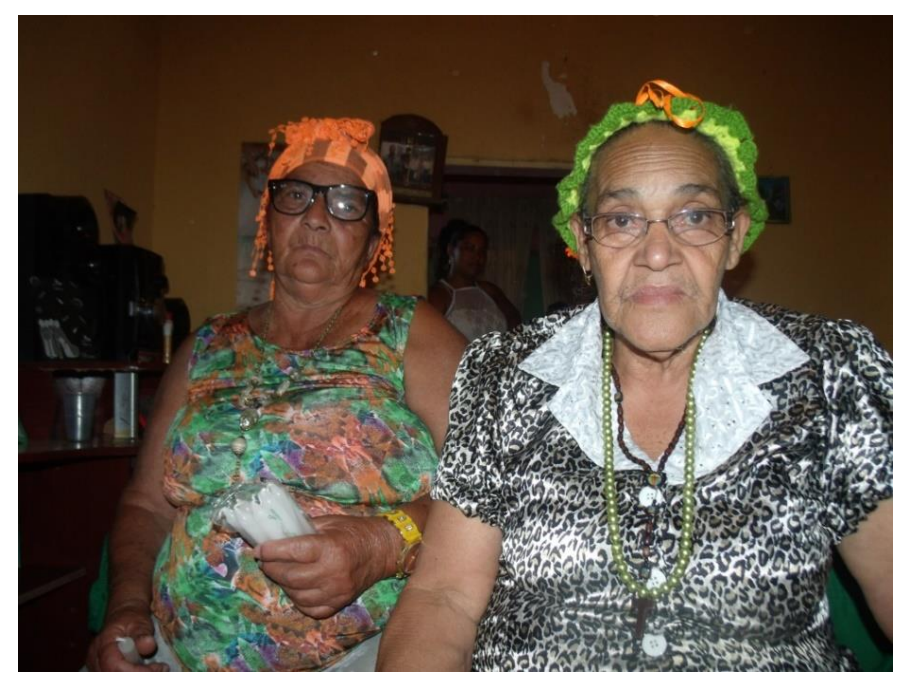

Figura 3. As rezadeiras: Tuga (à esquerda) e Bezinha (à direita). Fonte: Acervo da pesquisa, janeiro de 2017

É importante destacar que na comunidade há uma distinção nítida entre o ofício de rezadeiras de Ladainha entre as rezadeiras ligadas a processos de cura. Estas duas religiosas desempenham os dois ofícios, sendo consideradas líderes religiosas na comunidade, além de se destacarem com a função social e cultural de repassar o ofício a outras mulheres do quilombo.

Encontramos similaridades entre as mulheres do Baixão com outras mulheres negras (Conceição 2015; Leite 2016,) que buscam "referências para construção de suas identidades e instrumentalização de suas lutas políticas" (Leite 2016: 129) diante de suas demandas que ultrapassam os limites das "fronteiras étnicas" (Barth 1998), reivindicam e reafirmam sua identidade étnica, religiosa, de gênero, raça e classe. As trajetórias dessas mulheres se confundem, pois têm como legado a sua rede ancestral de saberes e, que no caso do Baixão, se reflete na relação de trabalho com a feira e a terra, além das práticas de cura, conhecimentos estes conectados a outras redes de saberes, que têm na oralidade a preservação desse universo mágico-religioso baseado na múltipla pertença expressa na devoção a Nossa Senhora Aparecida e a referências a entidades da Umbanda e do Candomblé, a exemplo de Iemanjá e Iansã.

A figura das rezadeiras é o elemento chave para a apreensão da experiência religiosa no Baixão, e representa a memória, os saberes, e especialmente, a presença simbólica de um

\footnotetext{
${ }^{3}$ Ao longo do texto, preferimos usar a forma como elas são conhecidas pelos moradores da comunidade.
} 
antepassado. Os saberes religiosos juntamente com a composição dos altares integram "o conjunto de símbolos sagrados, tecido numa espécie de todo ordenado, é o que forma um sistema religioso" (Geertz 1989: 95).

Conforme Eliade (1972), a experiência religiosa está suscetível de revelar-se como sacralidade cósmica e, estes símbolos, quando elevados à categoria de sagrados, deixam de ser meros objetos e passam a ser outra coisa e, paradoxalmente, continua a serem eles mesmos. Esta mesma relação se dá na composição do conjunto de símbolos dos altares das rezadeiras da comunidade. Esta compreensão subjetiva de símbolo também é tecida a partir do termo hierofania, que se refere a uma realidade que não pertence ao nosso mundo natural, profano, e está para além da visão do homem ocidental moderno. Nos altares, por exemplo, a hierofania é a demarcação do "lugar" nesse universo cósmico, que não pertence ao mundo visível. É o ato de manifestação onde o sagrado se mostra (Eliade 1972; 1992). Os altares representam o lugar em que as rezadeiras intercedem aos moradores para agradecimentos ou pedidos, mais do que isso, é o lugar onde elas se constituem enquanto pessoa.

Por outro lado, nem sempre há uma separação entre o sagrado e o profano, uma vez que eles se mesclam e intercambiam no processo de significação dos modos de vida cotidiana e na experiência religiosa das rezadeiras. Nessa perspectiva, o conjunto de entidades que povoa o imaginário dos moradores do Baixão é representado por Cosme e Damião, Santa Bárbara, Iemanjá, Bom Jesus da Lapa, Nossa Senhora Aparecida, Santa Luzia, São Sebastião, Santo Expedito e outros. Este panteão é reverenciado nas ladainhas, nas procissões e nos altares da maioria das residências, especialmente as referências a Cristo Crucificado, Cosme e Damião, Nossa Senhora Aparecida, São Sebastião e Santa Luzia. O Cristo Crucificado representa a devoção e peregrinação a Bom Jesus da Lapa, tradição trazida pelos antepassados.

Estas entidades (mestres, caboclos e santos) são também conhecidas como encantados que "[...] são concebidos como espíritos de homens e mulheres que morreram ou então passaram diretamente deste mundo para um mundo mítico, encantaram” (Prandi 2011: 7). Esse processo de correspondência simbólica "mágico-religiosa" que compõe o panteão brasileiro é resultado da pluralidade das religiões afro-brasileiras ou afro-índio-brasileiras que se dá principalmente pela justaposição de entidades de origem africana, em que os grupos da nação nagô ou iorubá, especialmente os de tradição de Oyó, Lagos, Ketu, Ijexá e Egbá, e os das nações jeje, sobretudo os mahis e os daomeanos recriavam no Brasil não somente a religião africana, mas também outros aspectos da sua cultura na África (Prandi 2000).

Apesar da múltipla pertença religiosa, as rezadeiras da comunidade se autodefinem como católicas. Este fato é semelhante ao encontrado em outras comunidades quilombolas, o que sugere que há um processo de negociação e de trocas dentro e fora do próprio grupo o que pode resultar numa estratégia de preservação dos saberes de seus ancestrais. Sobre as raízes do sincretismo religioso no Brasil, Prandi (2000) reitera que para sua sobrevivência e demonstração 
emblemática de ser brasileiro e católico, o negro se viu obrigado a incorporar-se numa cultura nacional, europeia, branca e cristã, mesmo quando se é africano e se cultuam os orixás, voduns e inquices. Ele não é mais capaz de saber de onde vieram seus ancestrais, e tanto no caso dos bantos como dos iorubás ou nagôs, as inúmeras variantes culturais locais "não sobreviveram como unidades autônomas e muitas foram totalmente perdidas no Brasil. Diferenças específicas foram apagadas, amalgamando-se em grupos genéricos conhecidos como jejes, nagôs, angola, etc" (Prandi 2000: 54).

Bezinha e Tuga estão na base da cadeia de transmissão oral de saberes ancestrais, tornando-as sacralizadas, pois além de rezadeiras têm a função de líderes espirituais, atributos considerados por elas como um dom dado por Deus e pelos seus antepassados. Assim como acontece com as sociedades de tradição africana, principalmente por se tratar de palavras transmitidas pelos antepassados ou de pessoas mais velhas da comunidade, a palavra tem valor sagrado e transmitida "de mestre a discípulo" em que a palavra é testemunho, tem um "caráter sagrado vinculado à sua origem divina e às forças ocultas nela depositadas”, numa cosmovisão onde todas as coisas se conectam (Bâ 1982: 169). Estas palavras são entoadas em suas ladainhas e ritos religiosos, como formas também de lembrar os pertencimentos daquele grupo social, bem como seus saberes.

Os seus altares tornaram-se o centro da nossa análise porque contam muito da história de suas rezadeiras e da comunidade, trata-se de um espaço sacralizado e socialmente identificado. Muitos são os símbolos e imagens que adornam os altares, como imagens que simbolizam algum santo e entidade, como também objetos que são comprados em viagens, ganhados e são tidos pelas religiosas como "objetos de agrado" desses entes sobrenaturais. Para as rezadeiras, os altares representam pertencimento étnico e a sua apresentação faz parte de um ritual de acolhida para quem chega às residências a procura de auxílio espiritual, por exemplo.

Por outro lado, a apreensão do seu significado está no campo do invisível e indizível e não pode ser revelado por inteiro, posto que se isto incorrer, ele deixa de ser sacralizado. Nas entrevistas com as rezadeiras apareceram interditos e impedimentos de ordem "invisível" que elas diziam "fazer mal falar". Respeitamos os silêncios, posto que estão para além da vontade individual e perpassa a uma realidade que faz parte da sua experiência simbólica com o sagrado. Na concepção de Eliade (1972: 8), a experiência imaginária "revela estruturas do real inacessíveis quer à experiência dos sentidos quer ao pensamento racional”, e esse mundo de significações é infinitamente superior do que a aparente realidade objetiva onde as imagens, os símbolos e os múltiplos universos (onírico, imaginário, ritualístico, mitológico) se complementam, tornandose perfeitamente inteligíveis no plano da mística e da metafísica.

A perpetuação desses saberes desde a origem da comunidade era operada apenas pelo patriarcado da família Machado do Santos. Atualmente, podemos considerar que esse papel social, cultural e religioso vem trazendo à tona o protagonismo dessas mulheres, uma vez que 
ao longo das gerações, elas foram construindo uma rede de saberes que dialogava com suas demandas e realidades, extrapolando os limites do seu núcleo familiar e adentrando outros territórios dentro e fora da comunidade. Daí a ideia de que gênero não deve ser compreendido em termos cristalizados e estáveis no espaço e no tempo.

Os altares e outros lugares sagrados das rezadeiras do Baixão, geralmente encontram-se inscritos em quartos de santos situados em um cômodo à parte da casa e que seguem regras próprias ou também podem ser organizados em "nichos" espalhados em lugares estratégicos da residência. Esses espaços sacralizados assemelham-se com a descrição feita por Sansi (2009) do quarto do santo de Madalena, uma mãe-de-santo iniciada no candomblé, na cidade de Cachoeira, cidade do recôncavo baiano conhecida por suas tradições africanas:

Os quartos do santo de Madalena são exuberantes cataratas de coisas diversas, desde emblemas e imagens a restos de oferendas e sacrifícios. Por exemplo, no altar de Oxum, deusa do amor, da riqueza e da água doce, vemos vasilhas cheias de objectos: imagens da sereia, perfumes, flores. Tudo coisas do “agrado" de Oxum. A parede está coberta de conchas, ojás dourados, panos usados nas festas para amarrar o orixá. À frente do altar há flores, restos de comida, candeias, dinheiro, brinquedos (Sansi 2009: 149).

No interior do recinto sagrado o mundo profano é transcendido e isto implica numa hierofania, "uma irrupção do sagrado que tem como resultado destacar um território do meio cósmico que o envolve e o torna qualitativamente diferente" (Eliade 1972: 20). Serge Gruzinski (2003) fala da existência destes espaços sagrados dentro das casas de povos indígenas do México em processo de ocidentalização com um lugar de demarcação de ancestralidade e ligação com povos locais.

Bezinha e Tuga são as principais lideranças religiosas da comunidade, elas realizam atendimentos em sua casa para aqueles que buscam orientação, proteção e cura tanto das demandas físicas quanto espirituais. Nesse sentido, a experiência religiosa dessas rezadeiras é pautada na relação com o grupo, isto é, com a comunidade. Se as rezadeiras desenvolvem diferentes rituais ligadas a práticas de cura, é mais por conta das necessidades do grupo do que suas próprias necessidades. Como afirmou Lévi-Strauss (2008):

É preciso que, por meio de uma colaboração entre a tradição coletiva e a invenção individual, se elabore se modifique continuamente uma estrutura, isto é, um sistema de oposições e de correlações que integre todos os elementos de uma situação total em que feiticeiro, doente e público, 
representações e procedimentos, encontrem cada qual o seu lugar (LéviStrauss 2008: 197).

\section{Dona Tuga}

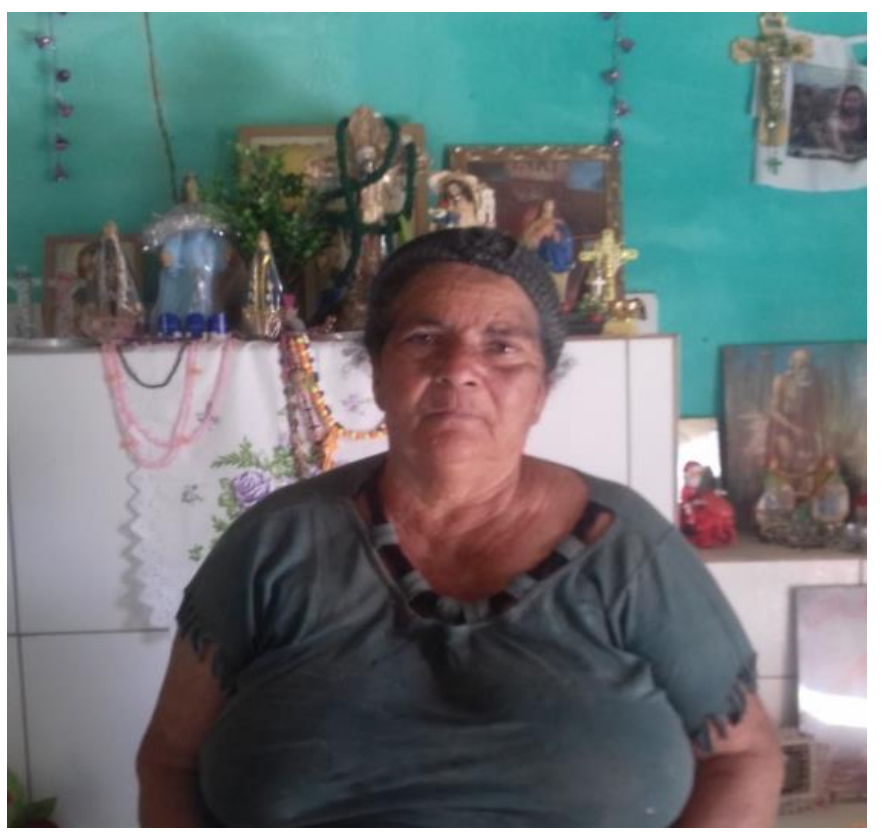

Figura 4. Dona Tuga. Fonte: Acervo da pesquisa, setembro de 2017

Jesuína Teresa de Jesus (76 anos), mais conhecida como Dona Tuga, é filha de Vitória Teresa de Jesus e neta de João Machado dos Santos, se destaca por ser uma mulher carismática e utiliza uma linguagem metafórica para falar da sua experiência religiosa, o que nos deixa subentendido que aquele lugar é a demarcação e a intersecção do sagrado com o profano. Devota a Bom Jesus da Lapa desde o dia em que pediu ao Santo que a curasse de uma enfermidade. Concedida a cura, isso há mais de 50 anos, ela passou a acumular em sua trajetória 32 romarias a Bom Jesus da Lapa. Por conta da idade e agravos com a saúde, envia a filha em seu lugar e assim renovar sua espiritualidade, já que segundo ela, não se pode "quebrar" a promessa ao Santo.

Atribui seus ensinamentos e práticas a um dom herdado de seu tio José Machado dos Santos, que foi um líder religioso na comunidade que realizava benzeduras e fazia garrafadas (preparação de mistura de ervas medicinais que tem o objetivo de cura de uma enfermidade

física ou espiritual) e graças ao seu anjo da guarda. Como descreve Goldman (2012), o dom está na ordem daquilo que a pessoa recebe independente de sua vontade, o que é dado, diferentemente daquilo que está no campo da iniciação, ou seja, daquilo que é feito.

Além do "dom" de cura, a rezadeira revela que tem dons mediúnicos que foram revelados em sonho, contando que certa vez seu anjo da guarda lhe avisou sobre a morte de um filho por 
afogamento, fato confirmado horas depois: "Eu tenho um anjo de guarda muito forte [...] Deus que é de livrar de uma coisa, aí seu anjo de guarda te avisa. O meu me avisa! [...] porque senão a queda pode ser pior" (Dona Tuga, entrevista concedida em setembro de 2017). Seguir as orientações do anjo da guarda implica manter a harmonia entre corpo e o espírito, natural e sobrenatural, profano e sagrado. E contrariar tais orientações dadas pelo anjo da guarda resultam em "fenômenos complexos que se expressam no plano fisiológico" (Lévi-Strauss 2008).

Segundo a religiosa, seu anjo da guarda lhe deu algumas proibições como não frequentar velórios, entre outros interditos, que caso sejam contrariadas tais determinações dadas pelo "anjo da guarda”, pode ocasionar em grandes consequências como o enfraquecimento da pessoa. Como afirmou Roger Sansi (2009: 143): "Essas entidades podem causar aflições físicas, mentais e sociais se as pessoas que eles querem 'para si' não cumprirem as suas obrigações para com eles", sendo que para muitas filhas-de-santo, a iniciação acontece não como vontade própria, mas está "submetida" a um Orixá, caboclo ou entidade.

As proibições seguidas pela religiosa abordam nas entrelinhas o processo de iniciação ou de passagem ligado às religiões afro-brasileiras que têm como um dos fundamentos seguir obrigações para o fortalecimento de uma força, energia - o axé. O processo iniciático pode durar alguns anos e tem o objetivo de preparar o corpo da pessoa, tornar a pessoa feita (Sansi 2009) e depende de "um conjunto de rituais mais ou menos tradicionais, que só podem ser desempenhados com o consentimento do sujeito e sob a condução de iniciados mais antigos do que ele" (Goldman 2012: 269).

Axé, palavra de origem africana, mais especificamente iorubá, designa um valor cultural que não existe nas sociedades que colonizaram o Brasil. Através do contar a história de um axé é possível retroagir no tempo e no espaço e até mesmo chegar aos tempos imemoráveis da Mãe África. Consiste numa força que pode ser deslocada de um espaço para outro e de uma pessoa para outra, e que está presente no visível e no invisível, podendo ser: "aumentada, diminuída, desligada, acumulada, transmitida e deixada por herança entre vivos, entre mortos e vivos, entre visíveis e invisíveis", sem que se esgote (Póvoas 2011: 256).

Dessa forma, podemos dizer que no Baixão, tendo como base as definições de Póvoas (2011) e Sansi (2009), Axé é entendido como a energia vital que rege a experiência religiosa, bem como, o processo de significação dos altares, como também, os saberes e fazeres dos moradores da comunidade.

Dona Tuga fez questão de mostrar o altar de seus santos que se localiza num cômodo à parte de sua residência, mais conhecido como quarto dos santos. Muitas imagens como Cosme e Damião, Cristo Crucificado, Iemanjá, São Lázaro, Nossa Senhora Aparecida, Nossa Senhora das Graças, Santo Expedito, entre outras divindades, compõem o altar. Em sua composição os símbolos e imagens que representam a devoção a Bom Jesus (Cristo Crucificado) têm maior 
predominância, tendo também como figura de destaque no centro do altar, as imagens de Iemanjá e Nossa Senhora Aparecida.

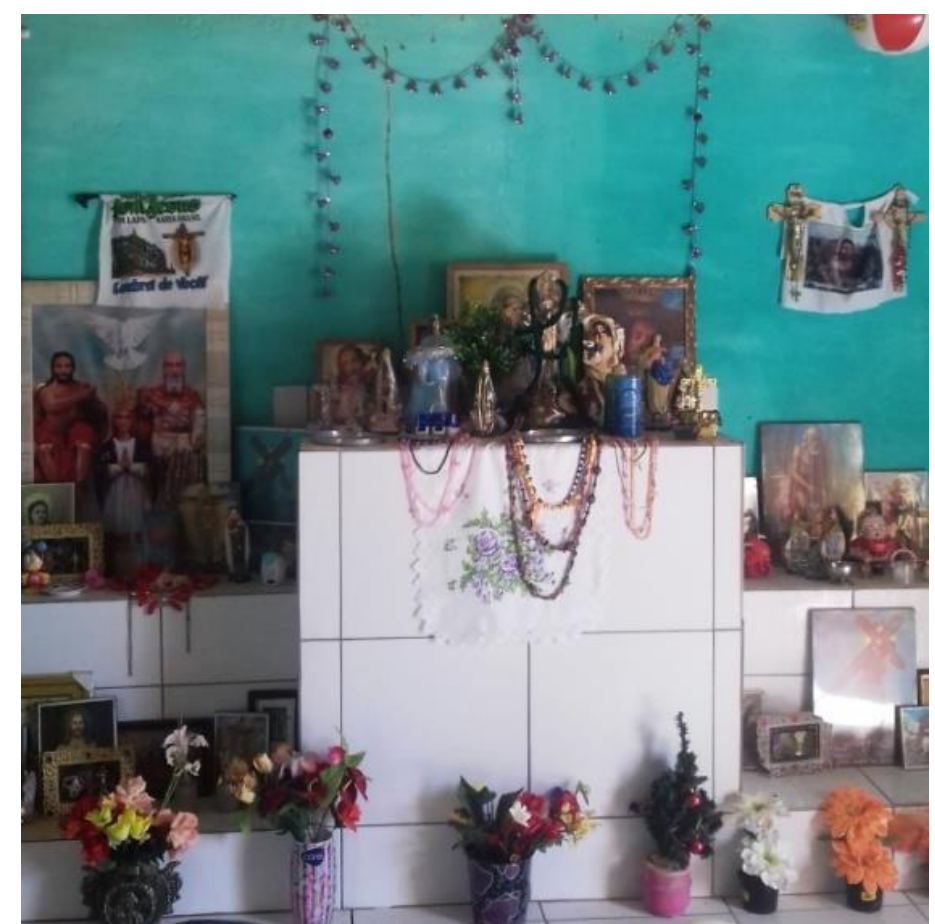

Figura 5. Altar do quarto dos Santos. Fonte: Acervo da pesquisa, setembro de 2017

Em um nível mais baixo do altar, um espaço dedicado à devoção a Cosme e Damião se destaca por estar enfeitado por brinquedos. Quando reza crianças, ela tem o costume de colocar os ramos atrás das imagens de Cosme e Damião. Segundo a tradição da Umbanda, os brinquedos são símbolos de "agrado" dos gêmeos Ibejis, filhos de Xangô e Yansã. As cores azul e rosa representariam esses Orixás. No catolicismo há uma relação dos santos com as cores, mas não tão fortemente quanto no candomblé ou na Umbanda. A forma como esses símbolos estão organizados e nas cores predominantes destacadas nas velas, cordões e objetos ao redor das imagens de santos, poderiam representar uma hierarquia em relação a outras entidades ou santos. O que se sabe é que estes símbolos buscam explicar e dar sentido a experiência religiosa de Dona Tuga. 


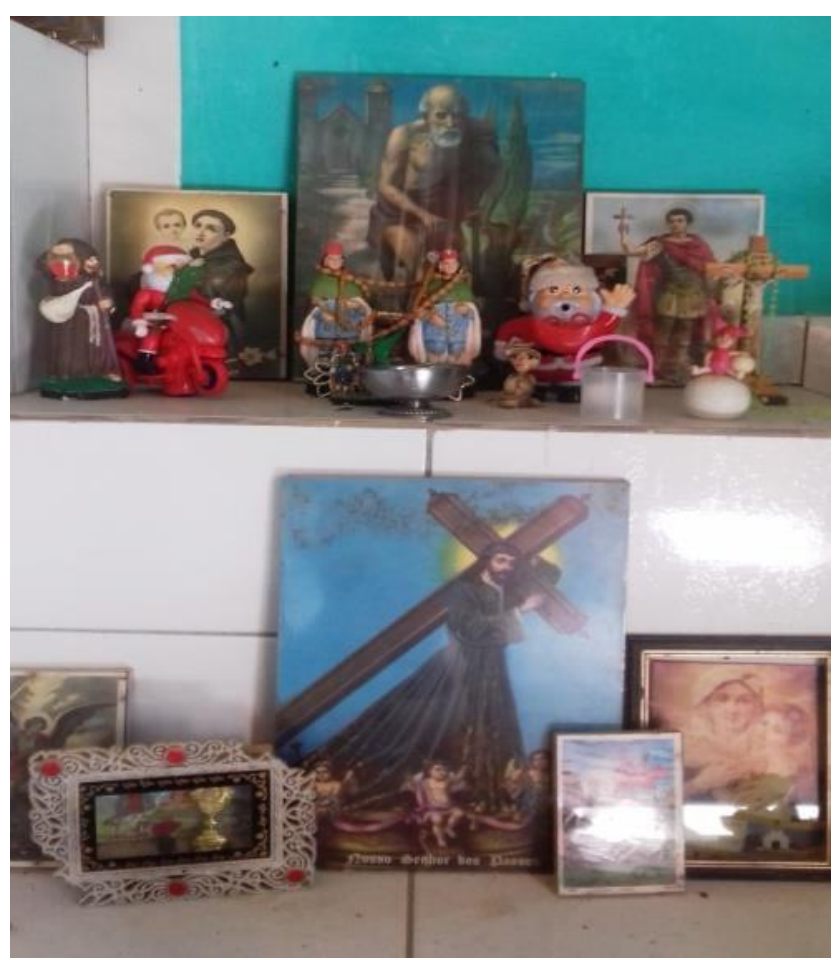

Figura 6. Espaço dedicado a Cosme e Damião. Fonte: Acervo da pesquisa, setembro de 2017

É interessante notar que os elementos sagrados dialogam entre si para a devoção aos santos católicos e aos Orixás ou encantados. Numa análise sobre o processo de significação destes símbolos, o que chama a atenção é a diversidade de colares disposto pelo altar, que segundo a rezadeira, não são guias, que sua fé é em um anjo da guarda. Quando indagada sobre quem seria o seu anjo da guarda, ela desconversou e afirmou não ter guias ou santos, inclinando a conversa para a sua fé católica. No entanto, nos símbolos que compõem o seu altar, nas suas práticas e no seu modo de vida nota-se a predominância de saberes de matriz africana.

\section{Bezinha}

Outra religiosa com grande reconhecimento pela comunidade é Izabel Teresa de Jesus (74 anos), conhecida por todos como Dona Bezinha. Ela é filha de Corina Rosa de Jesus e Emídio Machado dos Santos, pertence a parentela dos Machado e dos Malaquias. Ela é casada com um primo de primeiro grau, Estevão Ribeiro dos Santos, popularmente chamado de Preto, único descendente de origem indígena na comunidade. ${ }^{4}$

\footnotetext{
${ }^{4}$ Seu Preto é conhecido pela comunidade como um homem sério e de pouca conversa. Essas características foram dadas também ao seu pai, traços que eram considerados pela comunidade a quem tem "sangue de índio". Essa representação é a principal referência que os moradores têm sobre a presença indígena na formação do Baixão.
} 


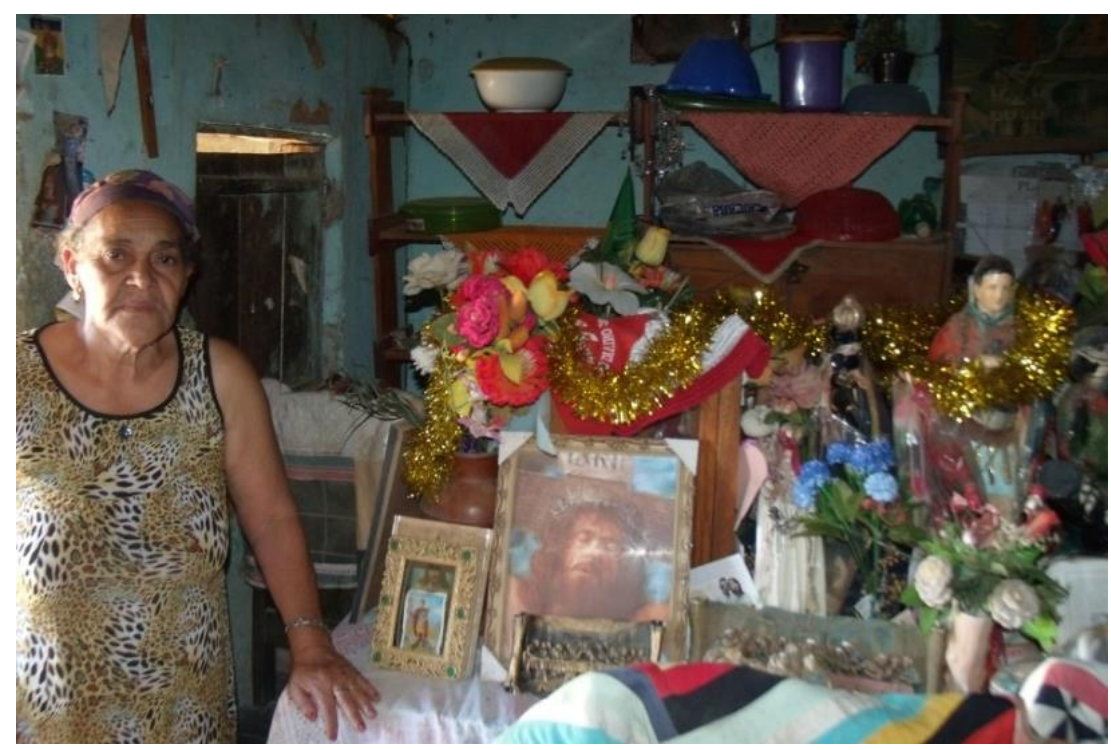

Figura 7. Dona Bezinha e um de seus altares. Fonte: Acervo da pesquisa, janeiro de 2017.

A ligação de dona Bezinha com o sagrado começou quando ainda jovem tinha o desejo de ser alfabetizada para aprender a rezar a Ladainha de Nossa Senhora. Como era uma "moça vistosa”, seu pai a proibiu de frequentar a escola, fato que não a impediu de aprender a oração. Certo dia ela começou a ter visões e a ouvir vozes que lhe ensinavam as ditas orações, o que a fez duvidar de sua lucidez. Pedindo orientações à sua mãe, ao que parece pressentia o dom de sua filha, a orientou para que ela seguisse o seu caminho.

Assim como Dona Tuga, Dona Bezinha apresenta atributos de dons mediúnicos em que as divindades se revelam em visões ou de forma onírica e a experiência religiosa está vinculada a um dom dado por Deus. Uma dessas revelações oníricas, uma mulher e um velho (coberto por um manto) em que ela faz correspondência simbólica com Nossa Senhora e Jesus, lhe ensinaram dia após dia a Ladainha, conforme relata: "Foi um milagre do pai que me ensinou. Não tem letra, professora, ninguém me ensinou. É a benção que Jesus me ensinou, dessa bênção pra cá, não tem quem tira” (Dona Bezinha, setembro de 2017). Uma característica do dom para essas rezadeiras é a ancestralidade. Dona Bezinha aprendeu com sua Tia Sabina, Romana e o esposo João Machado, que era curandeiro e considerado como o mito fundador da comunidade. A ambos era atribuído uma relevância social e religiosa em que possuíam dons mediúnicos e de cura. Nesse sentido, "receber" o dom não depende de sua vontade, mas da vontade de seus antepassados, que ela os coloca num lugar sacralizado, assim como as entidades que regem suas ações, como relata: "Então aquilo veio caminhando aquelas coisas pra mim e eu recebi" (Dona Bezinha, setembro de 2017). Na experiência religiosa dessas mulheres podemos observar a rede ancestral de saberes do axé, que na concepção de Póvoas (2011: 255), "herda-se geneticamente" e por herança. "Neste caso não há necessidade de advogado nem juiz: o axé dita as normas”. 
$\mathrm{Na}$ sua casa a devoção a santos e divindades estão por toda a parte, tornando a sala de sua casa um local sagrado. É tida como uma sacerdotisa que realiza bênçãos em casamentos. ${ }^{5}$ É considerada como rezadeira por rezar ladainhas e realizar benzeduras. Seu quintal é composto de muitas ervas medicinais às quais ela usa pra seu próprio consumo e para realizar benzeduras, banhos e chás. Nesses espaços sagrados há uma variedade de símbolos que juntamente com as imagens, principalmente a de Cristo Crucificado, Nossa Senhora de Fátima, Nossa Senhora Aparecida e Santo Expedito compõem os elementos de sua devoção.

Em visita a sua casa, nos foi apresentado seus altares, que estão em toda parte da sala, contando toda a sua trajetória religiosa, iniciada na religião de matriz africana e que hoje está voltada para o catolicismo: "Tem mais de 40 anos que eu suspendi, mas suspendi assim tudo o que eu quero ela me ajuda. Ela é a luz" (Dona Bezinha, setembro/2017). Esta narrativa revela as fronteiras e o processo de negociação entre o universo mágico-religioso entre divindades de matriz africana com os santos do catolicismo, sobretudo que há uma divindade que rege sua experiência religiosa.

A devoção a santos católicos e a divindades/encantados, especialmente as femininas, estão presentes na coleção de objetos e imagens das estantes, mesas de centro, mesas de canto, por toda parte da sala. Em outro canto da casa, encontra-se uma mesa em que os símbolos negociam com sua religiosidade católica. Os espelhos, o pé de pimenta, o bibelô da galinha d'angola, revistas com figuras femininas e os dois vasos de cerâmica, que estão de certa forma ocultados pelos ramos artificiais de arruda, conferem funções sagradas e ritualísticas a esta coleção de objetos. Nesses espaços não vimos ou não estava explícita a composição de colares ou guias, diferentemente de Dona Tuga em que os colares ou guias estão no centro do altar.

Ao falar da sua devoção às divindades, Dona Bezinha encontrou uma forma de ressignificar sua origem religiosa de matriz africana com a religiosidade católica, mais especificamente a sua devoção à Legião de Maria. Segundo ela, essa fé católica é graças à interferência de Padres de Vitória da Conquista que chamavam a sua atenção sobre sua crença e a convidava para participar das missas e pregações, o que levou a "suspender" seus guias.

\footnotetext{
5 A religiosa chama as bênçãos que faz em cerimônia de casamento como o "alô na mesa" que é realizado após o jantar com a presença dos noivos, padrinhos e convidados. É tido como um ritual que abençoa o casamento.
} 


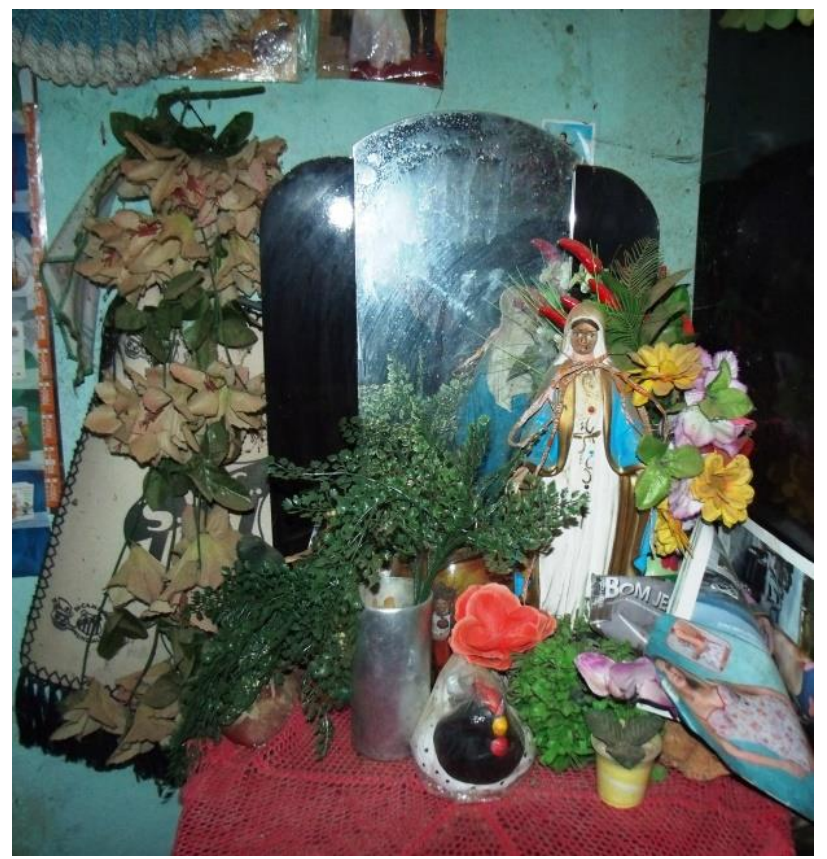

Figura 8. Altar de Dona Bezinha. Fonte: Acervo da pesquisa, janeiro de 2017.

Apesar dessa interferência do catolicismo em sua experiência religiosidade, sempre em suas narrativas há uma ênfase no legado religioso de seus antepassados. Ela reafirma a sua devoção aos santos e guias espirituais, sobretudo as femininas que sempre lhes aparecem em sonho ou interpelam para ações que ela considera como boas e que não causam mal a outras pessoas, tal revelação está para além de sua experiência onírica, manifesta em seu contato direto com o sagrado:

Eu tenho o poder de ver tudo quanto é coisa boa e coisa ruim [...] Eu tenho São Jorge, Jesus de Nazaré, Santa Ana, Janaína é minha santa, é aquela que tem o rabo [...] Tem guias que é sujo. Os guias de Nossa Senhora e Bom Jesus é guia de luz. [...] O sujo é aquele que só pede pra fazer briga, intriga. Aquele não é de Deus não. Os guias bom: Regina, Janaína, Marta, São Jorge, sereia do mar (Entrevista com dona Bezinha, setembro/2017. Grifos nossos).

Esta narrativa reverbera aspectos da tradição africana em que o universo é constituído de forças em contínuo movimento, e a manipulação dessas mesmas forças, da magia, visa restaurar o equilíbrio, a harmonia do homem. Na concepção europeia, magia carrega valor negativo, enquanto em África designa o controle das forças. "Nem a magia nem o destino são maus em si. A utilização que deles fazemos os tornam bons ou maus” (BÂ 1982: 174). Podemos 
notar que há uma ênfase a Janaína, que ela afirma ser sua guia. Na Umbanda é chamada de cabocla Janaína, pertencente à Linha das águas ou das sereias que são regidas especialmente pelo Orixá Iemanjá, estes símbolos estão presentes nos altares juntamente com os seus objetos de agrado.

Outro local sagrado na casa de Dona Bezinha é um quarto dos Santos que fica localizado em um cômodo ao lado da casa e onde anualmente mantém a tradição de montar um presépio em homenagem ao Menino Jesus, a São Sebastião, a Nossa Senhora Aparecida e outros santos de sua devoção. O presépio é montado antes do Natal e desmontado no dia 20 de janeiro, dia de São Sebastião, em que acontecem as ladainhas e é oferecido almoço para toda a comunidade. Tanto na Umbanda quanto no Candomblé, São Sebastião é sincretizado com Oxóssi, um dos principais Orixás e uma das formas de reverenciá-lo é com oferenda de alimentos. Dessa maneira, a rezadeira mantém a sua devoção a Santos e Orixás num contexto de negociação, em que as datas e tradições cristãs são pano de fundo para a manifestação da sua experiência com o profano e o sagrado também na religião de matriz africana.

A montagem do presépio carrega uma simbologia representada pelas bonecas que são compradas anualmente durante a Romaria a Bom Jesus da Lapa. Neste espaço sagrado o que chama a atenção são as bonecas penduradas pelo pescoço no teto do quarto, enquanto outras são organizadas no chão formando um emaranhado de corpos de bonecas. Da forma como estão organizados traz uma alusão à morte ou enforcamento. Entretanto, não temos respostas para tal arrumação e essa é apenas uma descrição reduzida de uma realidade que não é visível ao alcance de nossa perspectiva ou da perspectiva de quem é de fora da comunidade.

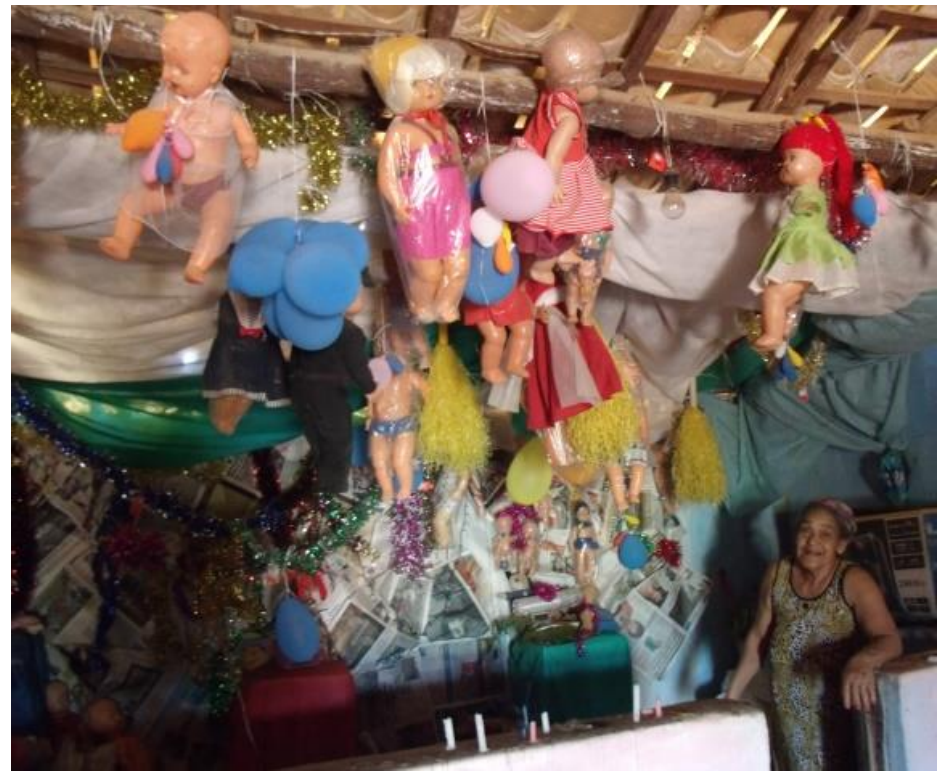

Figura 9. Presépio de Dona Bezinha. Fonte: Acervo da pesquisa, janeiro de 2017. 
Dona Bezinha salienta a presença de um casal de bonecos (próximo aos balões azuis), que são os principais arquétipos nessa composição: Valentino, boneco vestido com um terno preto e é considerado o namorado das bonecas, e Jordélia, sua namorada, é tida como a principal boneca. Pelo fato de usar um terno e ser o único entre as bonecas, segundo a descrição da religiosa, parece ter um poder de encantamento sobre as bonecas dando status de sacralidade. Tal descrição também nos remete a uma representação "profana" dos malandros da umbamba, a exemplo, um homem de muitas mulheres.

Pimentel (2011) faz uma análise do malandro enquanto personagem inserido numa categoria mental, social e por fim espiritual - numa teia de representações, simbolismos e imaginários que o situam no campo do sagrado e do profano. A figura do "malandro, assim como as outras entidades, é um todo que inclui vestimenta, apetrechos, acessórios, canção, ritmo, público, demanda, espaço, tempo, porquês e pra quês" (Pimentel, 2011, p. 441).

Nesse sentido, a ornamentação do presépio quebra com a visão cristã que tem como centro o nascimento de Jesus, e passa a ter como arquétipos bonecos e bonecas, conferindo particularidades em relação aos rituais e saberes das outras religiosas aqui abordadas. Perguntamos a Dona Bezinha quando se iniciou essa devoção de montagem de presépios com as bonecas, ela nos dá a seguinte resposta:

Quando eu vou pra Lapa, que todo ano eu ia, me dá assim um toque deu comprar assim pra minha Santa, e todo ano eu trazia duas, três. Os enfeites dos meus santos quando é pra eu comprar, eles toca em mim pra eu comprar. [...] 0 meu santo me toca pra tudo, pode ter milhões de pessoas e eu já viajei com os padres e aí já me abençoou. [...] eles [os santos] toca assim pra fazer só o bem, o mal de jeito nenhum. [...] Quando é pra eu rezar, Deus me toca tudo, eu já vou preparada, nada me trapalha, só um milagre dele [apontando para o céu] [...] só Nossa Senhora pra me tocar (Dona Bezinha, 2017. Grifos nossos).

Em sua fala, sugere que há mais de uma entidade que rege as suas ações. A peregrinação a Bom Jesus da Lapa e a aquisição dessas bonecas estão para além da sua vontade, envolve o ritual de devoção e o cumprimento de obrigações em que o santo por meio de visões, sonhos ou outra manifestação inconsciente age sobre ela e todo esse processo ritualístico é negociado com sua crença católica. Não há uma crença sem a outra, elas se conectam e traduzem no que aqui definimos como a experiência religiosa das rezadeiras do Baixão. 


\section{Considerações Finais}

Dentre os vários saberes que permeiam o cotidiano na comunidade do Baixão, citamos as principais manifestações religiosas, sendo ainda que há muitas outras que esta pesquisa não conseguiu alcançar. No entanto, a pesquisa apontou que as práticas religiosas nesta comunidade que têm como figura central a mulher e sua relação com o sagrado, e aí está circunscrito a ligação entre o sagrado e o profano, ancestralidade e pertencimento. O que propomos nesta pesquisa é só uma das infinitas análises sobre o leque inesgotável da rede de significações religiosas do Baixão e como este conhecimento rege os viveres e saberes das religiosas e de outros moradores desta comunidade quilombola, além de contribuir decisivamente para os pertencimentos identitários desta comunidade.

Assim, a religiosidade do Baixão se traduz numa variedade de símbolos, gestos, cantorias, orações e imagens tendo como devoção principalmente, as divindades de Cristo Crucificado que se concretiza na crença a Bom Jesus da Lapa, a Nossa Senhora Aparecida e a Iemanjá. Ao trazer para a análise os altares de Dona Bezinha e Dona Tuga não é na intenção apontar se estes espaços sagrados representam uma ou outra religião, e sim, problematizar os elementos étnicos presentes na religiosidade da comunidade que têm como referência a relação do feminino com o sagrado e de que forma tais elementos contribuem na formação identitária, sobretudo das mulheres analisadas. Por outro lado, a multiplicidade de significações dos saberes dessas mulheres, nos traz a certeza de que, como afirmou Eliade (1979: 16), traduzir uma imagem ou um símbolo "reduzindo a um só dos seus planos de referência, é pior do que mutilá-la: é aniquilála, anulá-la como instrumento de conhecimento".

$\mathrm{Na}$ experiência religiosa da comunidade é incomensurável o legado de seus antepassados que tem como esteio os vínculos familiares e os saberes de matriz africana, que também são atravessadas por elementos, memórias e saberes do catolicismo, o que caracteriza uma múltipla pertença religiosa.

Como falamos anteriormente, não buscamos respostas para definir a experiência religiosa na comunidade, mas problematizar a rede de saberes que permeiam as interações sociais e que costura o processo de significação de todos esses símbolos, posto que tentar definila ou explicá-la integralmente, tal experiência perderia seu status de sacralidade. Os altares e seus símbolos representam continuidades e rupturas entre o catolicismo e as religiões afrobrasileiras, o que nos permite dizer que esses espaços sagrados são o conjunto da ancestralidade, da história social e da memória e a intersecção entre o passado e presente, sagrado e profano.

Por fim, podemos inferir que essas religiosas produzem inovações nos seus rituais, produzindo "novas entidades" e elementos novos em seus altares, uma vez que esses espaços sagrados dialogam entre si para a perpetuação de práticas ancestrais do Baixão, bem como a constituição do panteão da comunidade. 


\section{Referências bibliográficas}

BÂ, Amadou H. 1982. "A tradição viva”. In: KI-ZERBO, Joseph (Coord.). História geral da África: metodologia e pré-história da África. São Paulo: Ática.

BERNARDINO-COSTA, Joaze; GROSFOGUEL, Ramon. 2016. Decolonialidade e perspectiva negra. Sociedade e Estado, v. 31, n. 1: 15-24. DOI 10.1590/S0102-69922016000100002

CARNEIRO, Sueli. 2011. Enegrecer o feminismo: a situação da mulher negra na América Latina a partir de uma perspectiva de gênero, 2011. Disponível em: https://www.geledes.org.br/enegrecer-o-feminismo-situacao-da-mulher-negra-naamerica-latina-partir-de-uma-perspectiva-de-genero/. Acesso em: 13 mai. 2020.

CONCEIÇÃO, Alaíze S. 2015. "Têm alguém que reza de olhado ai??": Cultura, Benzeções e Religiosidades no Recôncavo (1950-1970). Universitas Humanas, v. 12, n 1-2: 79-89. DOI 10.5102/univhum.v12i1.2967

ELIADE, Mircea. 1972. Imagens e Símbolos. Lisboa: Arcádía.

ELIADE, Mircea. 1992. O sagrado e o profano. São Paulo: Martins Fontes.

GEERTZ, Clifford. 1989. A Interpretação das Culturas. Rio de Janeiro: LTC.

GOMES, Camilla de Magalhães. 2018. Gênero como categoria de análise decolonial. Civitas Revista de Ciências Sociais, v. 18, n. 1: 65-82. DOI https://doi.org/10.15448/19847289.2018.1.28209

GOLDMAN, Marcio. 2012. O dom e a iniciação revisitados: o dado e o feito em religiões de matriz africana no brasil. Mana - Estudos de Antropologia Social, v. 18, n. 2: 269-288. DOI 10.1590/S0104-93132012000200002

GRUZINSKI, Serge. 2003. A colonização do imaginário: sociedades indígenas e ocidentalização no México espanhol. Séculos XVI-XVIII. São Paulo: Companhia das Letras.

HALBWACHS, Maurice. 2006. A Memória Coletiva. Tradução de Beatriz Sidou. 2. ed. São Paulo: Centauro.

LEITE, Maria Jorge dos Santos. 2016. Movimento Social Quilombola: processos educativos. Curitiba: Appris.

LÉVI-STRAUSS, Claude. "O feiticeiro e sua magia”. In: Antropologia Estrutural. São Paulo: Cosac Naify, 2008.

LIMA, Vivian. Ingridy de Carvalho; NASCIMENTO, Washington. Santos. 2018. Nações, fronteiras e relações étnicas na comunidade indígena-quilombola do Baixão (Vitória da Conquista, BA). Revista Ciências Sociais Unisinos, v. 54: 21-36. DOI 10.4013/csu.2018.54.1.03

MEIHY, Jose Carlos Sebe Bom. 2005. Manual de história oral. São Paulo: Loyola. 
MEIHY, Jose Carlos Sebe. 2000. "Desafios da história Latino-americana: o caso do Brasil”. In: FERREIRA, Marieta de Moraes; FERNANDES, Tania Maria; ALBERTI, Verena. (orgs.) História oral: desafios para o século XXI. Rio de Janeiro, Editora Fiocruz. pp.85-115

MCCLINTOCK, Anne. 2010. Couro imperial: raça, gênero e sexualidade no embate colonial. Trad. Plínio Dentzien. Campinas: Editora da Unicamp.

OLIVEIRA, Eduardo David de. 2012. Filosofia da ancestralidade como filosofia africana: Educação e cultura afro-brasileira. Revista Sul-Americana de Filosofia e Educação, n 18: 2847. DOI 10.26512/resafe.v0i18.4456

OLIVEIRA, Eduardo David de. 2018. Epistemologia da ancestralidade. (mimeo). Disponível em: https://filosofia-africana.weebly.com/uploads/1/3/2/1/13213792/eduardo_oliveira__epistemologia_da_ancestralidade.pdf

PIMENTEL, Pedro Guimarães. 2011. O processo de sacralização do malandro e a ressignificação da personalidade histórica. Mneme - Revista de Humanidades, v. 12, n.29: 435-462.

POLLACK, Michael. 1989. Memória, esquecimento e silêncio. Estudos Históricos, vol. 2, n. 3: 3-15.

POLLACK, Michael. 1992. Memória e identidade social. Estudos Históricos, vol. 5, n. 10: 200212.

PORTELLI, Alesssandro. Memória e diálogo: desafios da história oral para a ideologia do século XXI. In: FERREIRA, Marieta de Moraes; FERNANDES, Tania Maria; ALBERTI, Verena. (orgs.) História oral: desafios para o século XXI. Rio de Janeiro, Editora Fiocruz. pp.67-72.

POUTIGNAT, Phelippe.; STREIFF-FERNART, Jocelyne. 1998. Teorias da etnicidade: seguido de Grupos étnicos e suas fronteiras de Fredrik Barth. São Paulo: UNESP.

PÓVOAS, Ruy. 2011. Da Porteira para Fora: mundo de preto em terra de branco. Ilhéus: Editus.

PRANDI, Reginaldo. 2000. De africano a afro-brasileiro: etnia, identidade, religião. Revista USP, São Paulo, n.46: 52-65. DOI 10.11606/issn.2316-9036.v0i46p52-65

PRANDI, Reginaldo. 2011. “Introdução”. In: PRANDI, Reginaldo (Org.) Encantaria Brasileira: o livro dos mestres, caboclos e encantados. Rio de Janeiro: Pallas.

SANSI, Roger. 2009. Fazer o santo: dom, iniciação e historicidade nas religiões afro-brasileiras. Análise Social, vol. 44, n. 1: 139-160.

SCOTT, Joan W. 1995. Gênero: uma categoria útil para análise histórica. Educação \& Realidade, vol. 20, n. 2: 71-79.

SILVEIRA, Éder da Silva. 2007. História Oral e memória: pensando um perfil de historiador etnográfico. MÉTIS: história \& cultura, v. 6, n.12: 35-43. 
sobre o autor e a autora

\section{Washington Santos Nascimento}

Professor adjunto do Instituto de Filosofia e Ciências Humanas da UERJ. Doutor em História Social pela Universidade de São Paulo (USP) e Mestre em Antropologia pela PUC -SP.

\section{Vivian Ingridy Carvalho Lima}

Mestra em Relações Étnicas e contemporaneidade pela Universidade Estadual do Sudoeste da Bahia, com graduação em Pedagogia pela mesma instituição. Graduada em Psicologia pela Universidade Federal da Bahia.

Contribuição de Autoria: A autora e o autor foram ambos responsáveis pela coleta, análise e redação do manuscrito.

Financiamento: A pesquisa não contou com financiamento público.

Recebido em 06/07/2020

Aceito para publicação em 08/07/2021 